\title{
HERBAL WINE PRODUCTION FROM FRUITS AND VEGETABLE WASTES AND PEELS
}

\author{
A. Waheed Deshmukh \\ Department of Chemical Engineering \\ Priyadarshini Institute of Engineering \\ Nagpur, Maharashtra, India
}

\author{
Sadiya A. Deshmukh \\ Department of Microbiology \\ R.T.M. Nagpur University \\ Nagpur, Maharashtra, India
}

\begin{abstract}
Production of herbal wine from fruits and vegetable waste and their peels was carried out by using different herbs, by simple fermentation process. Different herbs such as tulsi, amla, ginger, tea leaves, aloe vera, and peppermint were used. The fermentation was carried out in two groups $A$ and $B$. In group $A$ all the herbs are used with pineapple, beetroot and carrot peels while in group $B$ all the herbs are used with pineapple, beetroot and carrot waste obtained after extracting their juices. The fermentation process was carried out in presence of active yeast (Saccharomyces Cerevisiae) at room temperature for 10 days. Various fermentation parameters such as $\mathrm{pH}$, specific gravity and alcohol content were determined for both the Groups A \& B at room temperature. The yield of alcohol contents was found to be 10.5 and $15.75 \%$ in peels and waste of selected material respectively. These herbal wines were found to be better in quality and due its various health benefits it can be widel1y used in medical application for preventing and treating various disorders.
\end{abstract}

Keywords: Herbal wine, Herbs, Fruits and vegetable waste, Peels, Health benefits.

\section{INTRODUCTION}

Wine is an alcoholic beverages made from fermented foods. Since from ancient times generally it is made from grapes, by fermenting grapes for specific duration of time, adding them in oak barrels followed by storage in wood barrels covered with leather cloth (Rathi, 2018). The earliest known winery is the 6100 year old Areni-1 winery in Armenia. Wine reached the Balkans by $4500 \mathrm{BC}$ and was consumed and celebrated in ancient Greece, Thrace and Rome. Throughout history, wine has been consumed for its intoxicating effects (https://en.m.wikipedia.org). Wines are also produced from other fruits like apple, berries, apricot, kiwi, strawberry, cherry, mango, banana etc. Wine made from fruits contains alcohol content of 5.5- $15.5 \%$ by volume. Wines are the healthful beverage that has been seen as a natural remedy for man's illness from early day and are said to aid recovery during convalescent period (Okonkwo and Dilar, 2016).

Herbal wines are the wine having medicinal properties which is usually prepared with incorporation of different herbs and medicinal plants. Herbal wines have anti-cancerous, antimicrobial, anti-diabetic and anti-oxidant properties. It has many health benefits like reduction in ovarian cancer, strengthening the bones and overall skeleton, cancer cell deteoriation, prevention of hearth strokes by keeping he coronary arteries clean, elevating lung functionality (Rathi, 2018). India has rooted evidences of expertise in Ayurveda where herbs, herbal powders and liquid herbal formulation are proved effective against diseases from common aliments to fatal diseases (Jayasundar, 2010a; Rathi, 2018b). Therefore these materials provide good adjuncts for herbal wine production having various health benefits and can be used to prevent diseases (Okonkwo and Dilar, 2016). The different types of herbs used for wine production are holy basil (Oscimum sanctum), peppermint (Menthe arvensis), ginger (Zinziber officinale), Indian gooseberry or amla (Emblica officinalis), aloe vera (Aloe barbadensis), tea (Camellia sinensis) etc. These herb plays a vital role for flavour enhancement and act as a preservative in wines (Rathi, 2018). The herb used in wine contains more tannins, polyphenols and lower acidity. Tannins found in the herbs are astringent in nature; they have aroma enhancing and antioxidant properties. They contain hydroxyl groups and carboxyl groups to form complexes with proteins (Ashok et al. 2012a; Rathi, 2018b). These antioxidants are found in flowers, fruits, steam, roots, bark and leaves. Now a days herbal infusions are trendy in wine. These herbs either in powder form or completely dry form are mix with base wine to increase its positive effect on health and over all body of human beings (Rathi, 2018).

The agricultural waste is generated in tonnes from beverages and fruit juice industries discard on daily basis. These wastes and peels contain 


\section{International Journal of Engineering Applied Sciences and Technology, 2021 \\ Vol. 5, Issue 9, ISSN No. 2455-2143, Pages 129-133 \\ Published Online January 2021 in IJEAST (http://www.ijeast.com)}

valuable nutrients components of simple sugar such as sucrose, glucose and fructose. Lignocellulose is a major structural component of woody and non woody plants (Shilpa et al.2013). The waste generated after extracting juice from fruits and vegetable and its peels can be used to make wine by Fermentation process. The fermentation is a simple process in which conversion of sugar into alcohol and carbon dioxide takes place in presence of yeast. In the present study the preparation of herbal wine from fruits and vegetable waste as well as its peel has been reported. The pineapple, beetroot and carrot waste and it peels are used to make wine. The herbs such as tulsi, amla, peppermint, aloe vera, ginger and tea leaves are added to wine to increase its flavour and health benefits. The fermentation is carried out in two groups A and B in an anaerobic fermenter. In group $\mathrm{A}$ all these herbs and peels of pineapple, beetroot and carrot are used while in group B all these herbs and wastes of pineapple, beetroot and carrot are used. The controlled fermentation was carried out with proper anaerobic conditions in both the fermenter to avoid bacterial growth. Various fermentation parameters such as $\mathrm{pH}$, specific gravity and alcohol content were determined for both the Groups A \& B at room temperature.

\section{MATERIALS AND METHODS}

A . Herbs, fruit and vegetable used

The pineapple (Ananas comosus), beetroot carrot and vegetable were purchased from the local market of Nagpur. The herbs used in the process such as holy basil/ tulsi (Oscimum sanctum), peppermint (Menthe arvensis), ginger (Zinziber officinale), Indian gooseberry/amla (Emblica officinalis), aloe vera (Aloe barbadensis) and tea leaves (camellia sinensis)are also brought from the local market. These materials were selected due to their some uncommon and unmatched medicinal properties which makes them special and essential in this work (Shiradhonkar etal.2014).

\section{B. Preparation of raw materials}

The pineapple, beetroot and carrot were washed thoroughly and peeled. The juice was extracted from pineapple, beetroot and carrot with help of juicer. The remaining waste left after extracting juice as well as its peels where used in this work. All the herbs were cleaned and washed under running water properly under running water. The ginger and amla were cuts into smaller pieces where as pulp from aloe vera was extracted. The extracts of tulsi, peppermint and tea leaves were prepared by soaking them in boiled water for 30 minutes.

The fermentation process was done in two groups $\mathrm{A}$ and $\mathrm{B}$ in a fermenter. In group $\mathrm{A}$ all the herbs with peels of pineapple, beetroot and carrot were used while in group B all the herbs with wastes of pineapple, beetroot and carrot were used. The proportions of herbs in both the fermenter A and B was maintained same as shown in Table 1.

\section{Preparation of yeast}

The dry yeast (Saccharomyces cerevisiae) were purchased from local market. The activation of dry yeast was done by taking $100 \mathrm{ml}$ each of lukewarm water having temperature of $45-50{ }^{\circ} \mathrm{C}$ in two beakers and adding 15 gms of sugar in each beaker with proper stirring then $15 \mathrm{gms}$ of dry yeast was added in both the beaker with proper stirring. After keeping both the beakers undisturbed for 10-15 minutes the froth formed will ensure that the yeast is being activated and then added to both the fermenters $\mathrm{A}$ and $\mathrm{B}$.

Table 1. Quantity of material used in both fermenter $\mathrm{A}$ and $\mathrm{B}$

\begin{tabular}{|l|l|c|c|}
\hline Sr.No. & \multicolumn{1}{|c|}{$\begin{array}{c}\text { Material } \\
\text { used }\end{array}$} & $\begin{array}{c}\text { GROUP A } \\
\text { (Fruit } \\
\text { Peels) }\end{array}$ & $\begin{array}{c}\text { GROUP B } \\
\text { (Fruit } \\
\text { Wastes) }\end{array}$ \\
\hline 1. & Tulsi leaves & $10 \mathrm{gms}$ & $10 \mathrm{gms}$ \\
\hline 2. & $\begin{array}{l}\text { Peppermint } \\
\text { leaves }\end{array}$ & $20 \mathrm{gms}$ & $20 \mathrm{gms}$ \\
\hline 3. & Tea leaves & $10 \mathrm{gms}$ & $10 \mathrm{gms}$ \\
\hline 4. & Ginger & $20 \mathrm{gms}$ & $20 \mathrm{gms}$ \\
\hline 5. & Aloe vera & $80 \mathrm{gms}$ & $80 \mathrm{gms}$ \\
\hline 6. & Amla & $150 \mathrm{gms}$ & $150 \mathrm{gms}$ \\
\hline 7. & Pineapple & $200 \mathrm{gms}$ & $150 \mathrm{gms}$ \\
\hline 8. & Beetroot & $80 \mathrm{gms}$ & $150 \mathrm{gms}$ \\
\hline 9. & Carrot & $100 \mathrm{gms}$ & $150 \mathrm{gms}$ \\
\hline
\end{tabular}

\section{Fermentation of wine}

The respective mixture of $\mathrm{A}$ and $\mathrm{B}$ were added in both fermenter along with the prepared activated yeast at the room temperature of about $27^{\circ} \mathrm{C}$ and maintained constant for subsequent time. The anaerobic fermentation was encouraged through airtight arrangement and providing an outlet for $\mathrm{CO}_{2}$ into the balloon. The fermentation was carried out at room temperature for next 10 days. After the fermentation the $\mathrm{pH}$, specific gravity and percentage alcohol content of fermentation broth was measured of both the fermenter $\mathrm{A}$ and $\mathrm{B}$ respectively.

\section{HEALTH BENEFITS OF HERBAL WINE}

The herbal wine prepared with incorporation of herbs possesses many health benefits. Herbs used act as enhancer, antioxidant and act as a preservatives in wine (Soni et al.2009a; Rathi, 2018 b). It has natural anti-bacterial constituents. They have numerous properties like anti-diabetic, 


\section{International Journal of Engineering Applied Sciences and Technology, 2021 \\ Vol. 5, Issue 9, ISSN No. 2455-2143, Pages 129-133 \\ Published Online January 2021 in IJEAST (http://www.ijeast.com)}

anti-cancerous, gastro-protectant, nerve soothing, pain killer (analgesic), good intestinal motility and cardiac activity (Rathi, 2018a; Stewart et al.1991b). It possesses anti-microbial and anti-bacterial against food borne pathogen (Rathi, 2018a; Kumar et al.2016b). The various health benefits of herbal wine is shown in table 2.

Table 2. Health benefit of raw herbs and material used for preparation of herbal wine

\begin{tabular}{|c|c|c|c|c|}
\hline $\begin{array}{l}\text { Sr. } \\
\text { no. }\end{array}$ & $\begin{array}{c}\text { Material used } \\
\text { (herbs, fruit and } \\
\text { vegetable) }\end{array}$ & $\begin{array}{l}\text { Parts of herb or } \\
\text { plant is used }\end{array}$ & Medicinal usage & Reference \\
\hline 1. & $\begin{array}{l}\text { Holy basil / tulsi } \\
\text { (Oscimum } \\
\text { sanctum) }\end{array}$ & Leaves of tulsi & $\begin{array}{l}\text { Therapeutic properties against } \\
\text { common ailments like cough, cold, } \\
\text { chronic dysentery, anti-cancerous, } \\
\text { anti-oxidant, anti-diabetic and good } \\
\text { gastro-intestinal effect. }\end{array}$ & $\begin{array}{l}\text { (Shiradhonkar } \\
\text { etal.2014);(Kaur } \\
\text { andKaur,2015) }\end{array}$ \\
\hline 2. & $\begin{array}{l}\text { Peppermint } \\
\text { (Menthe arvensis) }\end{array}$ & Mint leaves & $\begin{array}{l}\text { Stimulating, stomachic and } \\
\text { carminative properties like } \\
\text { indigestion, gastro-intestinal, } \\
\text { antiemetic, lowers cholesterol and } \\
\text { lower the activity in liver enzyme. }\end{array}$ & $\begin{array}{c}\text { (Shiradhonkar } \\
\text { etal.2014) } \\
\text { (Joshi et al.2014) }\end{array}$ \\
\hline 3. & $\begin{array}{l}\text { Tea } \\
\text { (Camellia } \\
\text { sinensis) }\end{array}$ & Leaves & $\begin{array}{l}\text { Rich in astringent compounds like } \\
\text { flavonoids that aids in protecting } \\
\text { against cough cold, fever. Anti- } \\
\text { cancerous, anti-diabetic and weight } \\
\text { loss properties. }\end{array}$ & (Kumar et al.2016) \\
\hline 4. & $\begin{array}{l}\text { Aloe vera } \\
\text { (Aloe } \\
\text { barbadensis) }\end{array}$ & Transparent slime & $\begin{array}{l}\text { Anti-fungal, anti-bacterial, anti-viral, } \\
\text { anti-inflammatory, anti-arthritic, } \\
\text { gastro-intestinal, tissue healing } \\
\text { properties. }\end{array}$ & (Trivedi et al.2012) \\
\hline 5. & $\begin{array}{l}\text { Ginger } \\
\text { (Zinziber } \\
\text { officinale) }\end{array}$ & Roots & $\begin{array}{l}\text { Effective against respiratory } \\
\text { congestions and common aliment like } \\
\text { cough and cold. Anti-oxidant, anti- } \\
\text { fungal, anti-cancerous. }\end{array}$ & $\begin{array}{l}\text { (Shiradhonkar } \\
\text { etal.2014) }\end{array}$ \\
\hline 6. & $\begin{array}{l}\text { Indian gooseberry } \\
\text { (Emblica } \\
\text { officinalis) }\end{array}$ & Berry & $\begin{array}{l}\text { Rich source of vitamin } \mathrm{C} \text {, good for } \\
\text { eye sight and hair growth, effective } \\
\text { against constipation and stomach } \\
\text { disorder. }\end{array}$ & $\begin{array}{l}\text { (Nandagopal and } \\
\text { Nair,2013); ( Soni et } \\
\text { al.2009); (Rana and } \\
\text { Singh, 2013) }\end{array}$ \\
\hline 7. & $\begin{array}{l}\text { Pineapple } \\
\text { (Ananas comosus) }\end{array}$ & $\begin{array}{l}\text { Fruits peels and its } \\
\text { waste after } \\
\text { extracting juice }\end{array}$ & $\begin{array}{l}\text { Improves bone and eye health, aiding } \\
\text { in digestion, prevent arthritis, cancer } \\
\text { and heart diseases, boosts immunity. }\end{array}$ & $\begin{array}{c}\text { (www.organicfacts.n } \\
\text { et) }\end{array}$ \\
\hline 8. & $\begin{array}{l}\text { Beetroot } \\
\text { (Beta vulgaris) }\end{array}$ & $\begin{array}{l}\text { Root peels and its } \\
\text { waste after } \\
\text { extracting juice }\end{array}$ & $\begin{array}{l}\text { Lowers blood pressure, increased } \\
\text { exercise capacity, boosts digestion, } \\
\text { prevent anemia, boosts blood } \\
\text { detoxification, prevent skin, lung and } \\
\text { colon cancer, strengthens heart and } \\
\text { reduces cholesterol. }\end{array}$ & $\begin{array}{c}\text { (www.organicfacts.n } \\
\text { et) }\end{array}$ \\
\hline 9. & $\begin{array}{l}\text { Carrot } \\
\text { (D. carota) }\end{array}$ & $\begin{array}{l}\text { Roots peels and its } \\
\text { waste after } \\
\text { extracting juice }\end{array}$ & $\begin{array}{l}\text { Reduced cholesterol, lower risk of } \\
\text { heart attacks, improve eye health, } \\
\text { weight loss friendly, detoxify the } \\
\text { body and improves skin, boost the } \\
\text { immune system and oral health. }\end{array}$ & $\begin{array}{c}\text { (www.organicfacts.n } \\
\text { et) }\end{array}$ \\
\hline
\end{tabular}

\section{RESULTS AND DISCUSSION}

After 10 days of fermentation, the wine formed in both the fermenter was assessed for its $\mathrm{pH}$, specific gravity and alcohol content.
The initial specific gravity of both the groups A and $\mathrm{B}$ before fermentation was found to be 1.04 . while after the fermentation the specific gravity of $\mathrm{A}$ and $\mathrm{B}$ was found to be 0.96 and 0.92 respectively 


\section{International Journal of Engineering Applied Sciences and Technology, 2021 \\ Vol. 5, Issue 9, ISSN No. 2455-2143, Pages 129-133 \\ Published Online January 2021 in IJEAST (http://www.ijeast.com)}

at controlled temperature. The $\mathrm{pH}$ of both the wine A and B was found to be 5.5 and 5.3 respectively. The alcohol content of both the herbal wine was calculated by the basic formula used by most home brewer to determine the alcohol content in the beverages as:

$$
\mathrm{ABV}=(\mathrm{OG}-\mathrm{FG}) \times 131.25
$$

Were $\mathrm{ABV}=$ alcohol by volume, $\mathrm{OG}=$ initial or original specific gravity, and $\mathrm{FG}=$ final specific gravity. The alcohol content in ABV of both the group A and B was found to be $15.75 \%$ and $10.5 \%$. The fermentation parameter of both the group A and $\mathrm{B}$ is shown in table 3 and Fig. 1

Table 3. Fermentation parameters of both herbal wines

\begin{tabular}{|c|c|c|c|}
\hline $\begin{array}{l}\text { Sr. } \\
\text { no. }\end{array}$ & Parameters & $\begin{array}{l}\text { GROUP A } \\
\text { (Fruit } \\
\text { peels) }\end{array}$ & $\begin{array}{l}\text { GROUP B } \\
\begin{array}{c}\text { (Fruit } \\
\text { wastes ) }\end{array}\end{array}$ \\
\hline 1. & $\mathrm{pH}$ & 5.5 & 5.3 \\
\hline 2. & $\begin{array}{l}\text { Specific } \\
\text { gravity }\end{array}$ & 0.96 & 0.92 \\
\hline 3. & $\begin{array}{l}\text { Alcohol } \\
\text { content } \\
(\mathrm{ABV})\end{array}$ & $15.75 \%$ & $10.5 \%$ \\
\hline
\end{tabular}

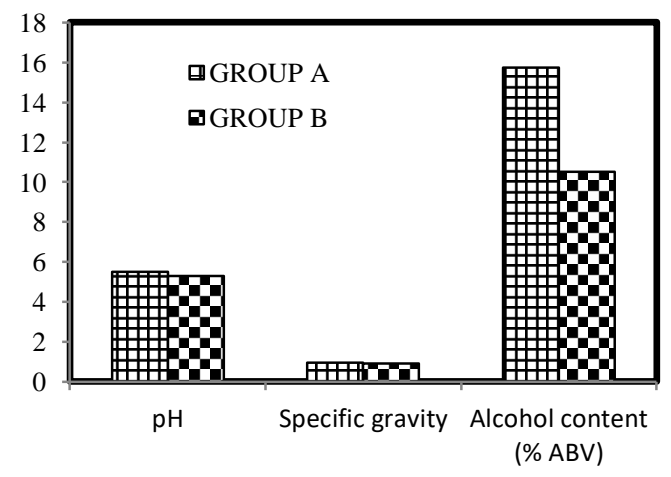

Fig.1 Fermentation parameters for both the wine

\section{CONCLUSION}

In the present study production of herbal wine by fruit and vegetable waste and its peels has been studied at controlled temperature. The herbal extracts used were found to complement the basic attributes of the wine when used in the specified amounts. The produced herbal wine was assessed for fermentation parameters such as specific gravity, $\mathrm{pH}$ and alcohol content by volume. The alcohol content was found to be more in the herbal wine $(15.75 \%)$ containing peels than that of herbal wine from fruit waste $(10.5 \%)$. Both the herbal wine formed is of red colour, acceptable taste and smell. Regular, but limited administration of these herbal wines would help in receiving benefits of the herbal extracts, thus, minimizing the need for synthetic medicines for treating various disorders. The combinations gave a novel product with better qualities, increased acceptability and wider applications The herbal wine formed is having many health benefits which can help in preventing various diseases and has wide medicinal application. Therefore these used herbs, waste and peels material may provide good adjuncts for wine and alcohol production. This may also lead to reduce seasonal losses of the fruits and vegetables as well as reduces waste load in the environment.

\section{REFERENCES}

[1] Kaur A, \& Kaur B. (2015). Production and comparative study of holy basil wine, banana wine and date wine. International Journal of Science and Research., (pp. 638-640).

[2] Rathi V. (2018). Herbal Wine : A Review. Journal of Nutrition and Weight loss, 3(2), (pp.113-117).

[3] Jayasundar, R. (2010). Ayurveda a distinctive approach to health and disease. Current Science,vol. 98 no.7 (pp. 908-914).

[4] Ashok, P. K. (2012). Tannins are astringent. Journal of Pharmacognosy and Phytochemitry,vol. 1, no.3, (pp. 45-50).

[5] G. Nandagopal \& Nair P. (2013). Production of wine from ginger and indian gooseberry and a comparative study of them over commercial wine. American Journal of Engineering Research vol. 3, no.5, (pp.19-38).

[6] Joshi V.K., John S., \& Abrol G.S. (2014). Effect of addition of extracts of different herbs and spices on fermentation behavior of apple must to prepare wine with medicinal value. National Academy of Science Letters, 37, (pp.541-546).

[7] Soni S., Bansal N. \& Soni R., (2009). Standardiztion of conditions for fermentation and maturation of wine from amla. Indian Journal of Natural Product and Resourses, Vol. 8, (pp.436-444).

[8] Shiradhonkar R. \& Dukre A. (2014). Fortification of wine with herbal extract: production, evaluation and therapeutic application of such fortified wines. IOSR Journal of Environmental Science, 
Toxicology and Food Technology, vol. 8, no.3, (pp. 9-14).

[9] Rana A. and Singh H. (2013). Bioutilization of wild berries for preperation of hgh valued herbal wines. Indian Journal of Natural Product and Resourses vol. 4, (pp.165-169).

[10] Stewart J. \& Wood M. (1991). Effect of ginger on motion thickness susceptibility and gastric function. Pharmocology vol. 42, (pp. 111-120).

[11] Trivedi N., Rishi P., Soni S., (2012). Production of herbal wine from 'Aloe vera' gel and evaluation of its effect against common food borne pathogens and probiotics. International Journal of Food and Fermentation Technology, vol. 2, no., 2, (pp.157-166).

[12] Chapadgaonkar S. and Malhotra G. (2013). Alcohol Production from Fruit and Vegetable Waste. International Journal of Applied Engineering Research,vol. 8, (pp.1749-1756).

[13] Okonkwo S. and Ali. (2016). Production and Analysis of Wine from Agricultural Wastes: Pineapple (Ananas comosus) peels, to act for suistainable Ecosystem. Chemistry and Material Research, vol. 8, (pp. 42-44).

[14] V. Kumar, (2016). Process optimization for the preperation of apple tea wine with analysis of its sensoryand physicochemical characteristics and antimicrobial activity against food- borne pathogens.Nutrafoods vol. 15, (pp.111121). 